\title{
Treatment of HIV-associated facial lipoatrophy: impact on infection progression assessed by viral load and CD4 count ${ }^{*}$
}

Tratamento da lipoatrofia facial associada ao HIV / AIDS: o impacto sobre a progressão da infecção avaliada pela contagem de CD4 e carga viral

\author{
Flávia Machado Gonçalves Soares ${ }^{1}$ \\ DOI: http://dx.doi.org/10.1590/abd1806-4841.2013895
}

Izelda Maria Carvalho Costa ${ }^{2}$

\begin{abstract}
BACKGROUND: HIV/AIDS-Associated Lipodystrophy Syndrome includes changes in body fat distribution, with or without metabolic changes. The loss of fat from the face, called facial lipoatrophy, is one of the most stigmatizing signs of the syndrome.

OвJестіVES: To evaluate the effect of FL treatment using polymethylmethacrylate (PMMA) implants on disease progression, assessed by viral load and CD4 cell count.

METHODS: This was a prospective study of 44 patients treated from July 2009 to December 2010. Male and female patients, aged over 18 years, with clinically detectable FL and who had never been treated were included in the study. PMMA implantation was done to fill atrophic areas. Laboratory tests were conducted to measure viral load and CD4 count before and after treatment.

RESULTS: Of the 44 patients, $72.72 \%$ were male and $27.27 \%$ female, mean age of 44.38 years. Before treatment, $82 \%$ of patients had undetectable viral load, which increased to $88.6 \%$ after treatment, but without statistical significance $(p=0.67)$. CD4 count before treatment ranged from 209 to 1293, averaging 493.97. After treatment, the average increased to 548.61. The increase in CD4 count after treatment was statistically significant with $p=0.02$.

CONCLUSION: The treatment of FL with PMMA implants showed a statistically significant increase in CD4 count after treatment, revealing the impact of FL treatment on disease progression. Viral load before and after treatment did not vary significantly.
\end{abstract}

Keywords: CD4-Positive T-Lymphocytes; HIV; HIV-Associated lipodystrophy syndrome; Polymethyl methacrylate; Viral load

Resumo: FundAMENTOS: A Síndrome Lipodistrófica Associada ao HIV/AIDS compreende alterações na distribuição da gordura corporal, acompanhada ou não de alterações metabólicas. A perda da gordura facial, chamada lipoatrofia facial, é dos sinais mais estigmatizantes da síndrome.

Objetivos: Avaliar o impacto do tratamento dalipoatrofia facial com implante de polimetilmetacrilato sobre a progressão da doença, avaliada pela contagem da carga viral e a contagem de células CD4.

Métodos: Estudo prospectivlipoatrofia facial clinicamente detectável e sem tratamento prévio. Foi realizado implante de polimetilmetacrilato para preenchimento das áreas atróficas. Foram realizadas contagem da carga viral e células CD4 antes e após o tratamento.

Resultados: Dos 44 pacientes, 72,72\% eram do sexo masculino e 27,27\% do feminino, e idade média de 44,38 anos. Antes do tratamento, $82 \%$ dos pacientes apresentavam carga viral indetectável, que aumentou para 88,6\% após o tratamento, mas sem significância estatística $(\mathrm{p}=0,67)$. A contagem de CD4 antes do implante variou de 209 a 1293, com média de 493,97. Após o tratamento, essa média aumentou para 548,61. O aumento do CD4 após o tratamento foi estatisticamente significativo, com $\mathrm{p}=0,02$.

Conclusão: O tratamento dalipoatrofia facial com implante de polimetilmetacrilato levou ao aumento estatisticamente significativo da contagem de CD4, mostrando impacto do tratamento da LF sobre a evolução da doença. A carga viral antes e após tratamento não variou de maneira estatisticamente significativa.

Palavras-chave: Carga viral; HIV; Linfócitos T CD4-Positivos; Polimetilmetacrilato; Síndrome de lipodistrofiaassociada ao HIV

Received on 18.11.2010.

Approved by the Advisory Board and accepted for publication on 17.09.2012.

* Work conducted at Hospital Regional da Asa Norte (HRAN) - Brasília (DF), Brazil.

Financial Support: None

Conflict of Interest: None

M.Sc., University of Brasilia (UnB) - MD, State Department of Health of the Federal District (SES-DF) - Brasília (DF), Brazil.

PhD in Dermatology, Federal University of São Paulo (UNIFESP) - Professor, Department of Dermatology, University of Brasília (UnB) - Brasília (DF), Brazil. 


\section{INTRODUCTION}

Since 1996, new anatomic and metabolic changes have been described in patients with HIV/AIDS, particularly in those undergoing antiretroviral therapy. Patients presented with peripheral fat atrophy and central fat accumulation, accompanied by insulin resistance and several abnormalities in serum lipids. ${ }^{1}$ These changes were later described as lipodystrophy and/or HIV-associated lipodystrophy syndrome (HIVLS).

Other anatomical changes include lipoatrophy of the face, upper and lower limbs and prominence of superficial veins, associated or not with accumulation of fat in the abdomen, neck and breasts. Metabolic changes include lipid alterations and abnormal glucose homeostasis, which may or may not be associated with body fat changes. ${ }^{2}$

The prevalence of lipodystrophy described in the literature varies widely; some articles describe rates of $7-84 \%$ among HIV/AIDS patients, in use or not of antiretrovirals. ${ }^{3-6}$

Given the difficulty to assess face fat (FL), the method most widely used to diagnose facial lipoatrophy includes a subjective description of changes in subcutaneous fat by the patient and the physician's clinical observation.?

The exact mechanism that leads to the development of anatomic and metabolic changes is still unclear. Mitochondrial toxicity associated with the use of nucleoside reverse-transcriptase inhibitors (NRTIs), deregulation of tumor necrosis factor $\alpha$ (TNF), inhibition of cytochrome P450 associated with protease inhibitors, local effect of HIV on cortisol production and other changes in steroid hormone levels have been described, among others. None of these hypotheses explain all aspects of the changes caused by the syndrome individually. The disease probably has a multifactorial cause. ${ }^{8}$

Although fat loss is also visible in the arms, legs and buttocks, the face is the region where it is most evident and impactful. ${ }^{7}$

Facial lipoatrophy consists of a progressive loss of facial fat, mainly due to decreased malar fat (Bichat fat pad) and temporal fat. As a consequence, new skin furrows develop and skin depressions and lines of expression become more prominent. This can result in a skeletal appearance. All this leads to wrinkling of the face and gives the individual an aged appearance. ${ }^{9}$ Furthermore, an emaciated and haggard face has brought back the old stigma of AIDS and fear of an involuntary and unintentional disclosure of an HIV status. ${ }^{10}$

As the symptoms worsen, many patients begin to show the typical characteristics of lipodystrophy syndrome, bringing back the stigma of AIDS and the need for specialists working with HIV/AIDS patients to identify these changes and seek treatment options. ${ }^{8,11}$

Changes in body image can be extremely disturbing in terms of psychosocial well-being, increasing the stigma of the disease.

Patients have described FL as a visible marker that identifies HIV carriers; it is perceived as the "face of AIDS," or the "Kaposi's sarcoma of the $21^{\text {st }}$ century". It also causes problems in social and family relationships, leading to the isolation of patients. One of the major consequences of FL is treatment withdrawal due to the psychosocial effects of body fat redistribution. $^{2}$

Given the prevalence of changes in fat redistribution, it is clear that HIV-associated facial lipoatrophy is becoming epidemic. It stigmatizes those affected causing a major impact on these patients' quality of life. These patients often show good disease control and are healthy, but their facial features suggest otherwise, and the psychological effects are often devastating. ${ }^{12}$

Patients with FL are exposed and cannot hide their condition. This can result in discrimination at work, it can affect relationships, sexual function and even adherence to treatment. This affects these patients' sense of well-being, as well as their body image and self-esteem. In some cases, patients become socially isolated. ${ }^{13}$

Disorders of body fat distribution associated with antiretroviral therapy are now considered irreversible and there are no therapeutic strategies that allow sufficient recovery of adipose tissue for a consistent clinical perception, as described in several studies.

Cutaneous implants are an important therapeutic option, with high levels of patient satisfaction. . $^{14,15}$ Among the fillers available on the market, polymethylmethacrylate (PMMA) is the material used to treat FL in the Unified Health System (SUS).

Considering the sometimes devastating effect of FL on the lives of patients, treatment leads to positive effects on their mental, emotional and social condition. Studies in the literature have shown improved self-esteem, interpersonal relationships and quality of life of patients undergoing treatment with various filler implants. ${ }^{14}$ There is also a report of improvement of depression in patients with AIDS treated with polylactic acid implants. ${ }^{16}$

However, there is no report about whether treatment of FL has an effect on the progression of $\mathrm{HIV} / \mathrm{AIDS}$.

The most accurate and widely used markers of HIV/AIDS infection are CD4 count and plasma viral load, which serve as reliable measures of disease progression. ${ }^{17}$ 
The objective of this study was to evaluate the effect of FL treatment using subcutaneous implants or supraperiosteal PMMA on the progression of HIV/ AIDS, as assessed by quantification of viral load and CD4 count before and after treatment.

\section{METHODS}

We conducted a prospective, experimental, descriptive-analytical study of 44 patients seen at the Facial Lipodystrophy Outpatient Service at Hospital Regional da Asa Norte - HRAN, State Department of Health of the Federal District - SES / DF from July 2009 to December 2010.

All patients were referred by infectious disease specialists working in the health network of the Federal District through a standard form filled with laboratory and clinical data attesting the good general health of the patients for them to undergo FL treatment.

Inclusion criteria were HIV-positive patients, antiretroviral users or not, 18 years old or older, of both sexes and with clinically detectable FL. Clinical assessment considered the medical report and the patients' reports on the loss of face fat. On clinical examination, the presence of lipoatrophy in the malar and/or zygomatic and/or pre-auricular and/or temporal regions was evaluated, as well as aggravation of furrows and/or visualization of temporal vessels. Patients undergoing ARV therapy should do it regularly throughout the treatment. The therapeutic regimen adopted should have been initiated at least six months before the start of the study. There could have been no changes to this regimen during this period. Patients undergoing changes in the treatment regimen or who initiated ARV use during the study were excluded.

Patients expressed the desire to undergo treatment with PMMA implants and agreed to participate in the study by signing the informed consent form.

All patients had their plasma viral load and CD4 count measured three months before and six months after treatment. The measurement of viral load and CD4 count before and after the implant was done in the same laboratory and the same standard laboratory techniques were used.

The areas to be filled were marked with the patient in the sitting position. Patients were then accommodated in chairs for a backrest tilted procedure.

Asepsis was done with gauze soaked in $70 \%$ ethanol and topical anesthesia was done with $4 \%$ lidocaine applied to the area to be treated 30 minutes before the procedure. In patients with a lower pain threshold, regional nerve block anesthesia was done (mentonian and infraorbital nerves).
The filler used was polymethylmethacrylate (Metacryll), produced and marketed by Nutricel. The PMMA used was provided by the program STD/AIDS in accordance with Ordinance 2582/GM of December 2, 2004.

The concentration of the PMMA used was 10\% for treatment of the temporal region and $30 \%$ for treatment of other areas. The application technique used was retro injection with previous aspiration. The material was subcutaneously or supraperiosteally injected, in a parallel and cross-fanning manner, to obtain satisfactory filling of the areas marked. Hemostasis was achieved with local compression. After the procedure, all patients were oriented to apply ice to the area treated, not to expose it to heat sources, not to practice physical activities, not to drink alcohol and avoid sun exposure for 7 days, as well as massage the areas treated. Paracetamol was prescribed in case of pain. As many sessions as necessary were done to complement the implant, with a 30-day interval in between sessions.

We compared plasma viral load and CD4 count obtained before and after treatment.

The statistical test used was Wilcoxon test.

\section{RESULTS}

Of the 44 patients studied, $32(72.72 \%)$ were male and $12(27.27 \%)$ female, with a male/ female ratio of 2.66 .

The average age of the patients was 44.38 years, with the youngest patient being 34 years old and the oldest, 62 years old.

Before treatment, $82 \%(\mathrm{~N}=36)$ of the respondents had a mean viral load of up to 50 viral copies $/ \mathrm{ml}$ of blood. The highest viral load prior to treatment was 31,300 copies $/ \mathrm{ml}$ of blood. After treatment, the percentage of patients with viral load below 50 viral copies $/ \mathrm{ml}$ of blood increased to $88.6 \%$ ( $\mathrm{N}=$ 39). Despite the increased percentage of patients with undetectable viral load, this increase was not statistically significant, with $p=0.67$. After treatment, the highest viral load detected was 122,694 copies/ml of blood. (Tables 1 and 2)

The mean CD4 count before treatment was 493.97. The highest value observed was 1293 and the lowest, 209. After treatment, the mean CD4 count increased to 548.61, and the maximum value found was 1485 and the minimum was 118 (Tables 3, 4 and Graph 1). This increase in CD4 count was statistically significant, with $\mathrm{p}=0.02$.

The highest increase found in CD4 count was that of a patient who had 581 cells $/ \mathrm{mm}^{3}$ before treatment and 1485 cells $/ \mathrm{mm}^{3}$ after treatment (Figures 1 and 2). 
TABLE 1: Viral load prior to treatment (number of viral copies / $\mathrm{ml}$ blood)

\begin{tabular}{lll}
\hline Viral load & Total & $\%$ \\
Up to 50 & 36 & 82 \\
Greater than 50 & 8 & 18 \\
Total & $\mathbf{4 4}$ & $\mathbf{1 0 0}$ \\
\hline
\end{tabular}

TABLE 3: Distribution of CD4 count (cells / $\mathrm{mm}^{3}$ ) per range before treatment

\begin{tabular}{ll}
\hline Range & Frequency \\
$100-199$ & 0 \\
$200-299$ & 9 \\
$300-399$ & 4 \\
$400-499$ & 15 \\
$500-599$ & 5 \\
$600-699$ & 3 \\
over 700 & 8 \\
\hline
\end{tabular}

TABLE 2: Viral load after treatment (number of viral copies / $\mathrm{ml}$ blood)

\begin{tabular}{lll}
\hline Viral load & Total & \% \\
Up to 50 & 39 & 89 \\
Greater than 50 & 5 & 11 \\
Total & $\mathbf{4 4}$ & $\mathbf{1 0 0}$ \\
\end{tabular}

TABLE 4: Distribution of CD4 count (cells / $\mathrm{mm}^{3}$ ) per range after treatment

\begin{tabular}{ll}
\hline Range & Frequency \\
$100-199$ & 1 \\
$200-299$ & 3 \\
$300-399$ & 10 \\
$400-499$ & 5 \\
$500-599$ & 9 \\
$600-699$ & 9 \\
over 700 & 7 \\
\hline
\end{tabular}

Graph 1: Distribution of patients by CD4 range before and after treatment

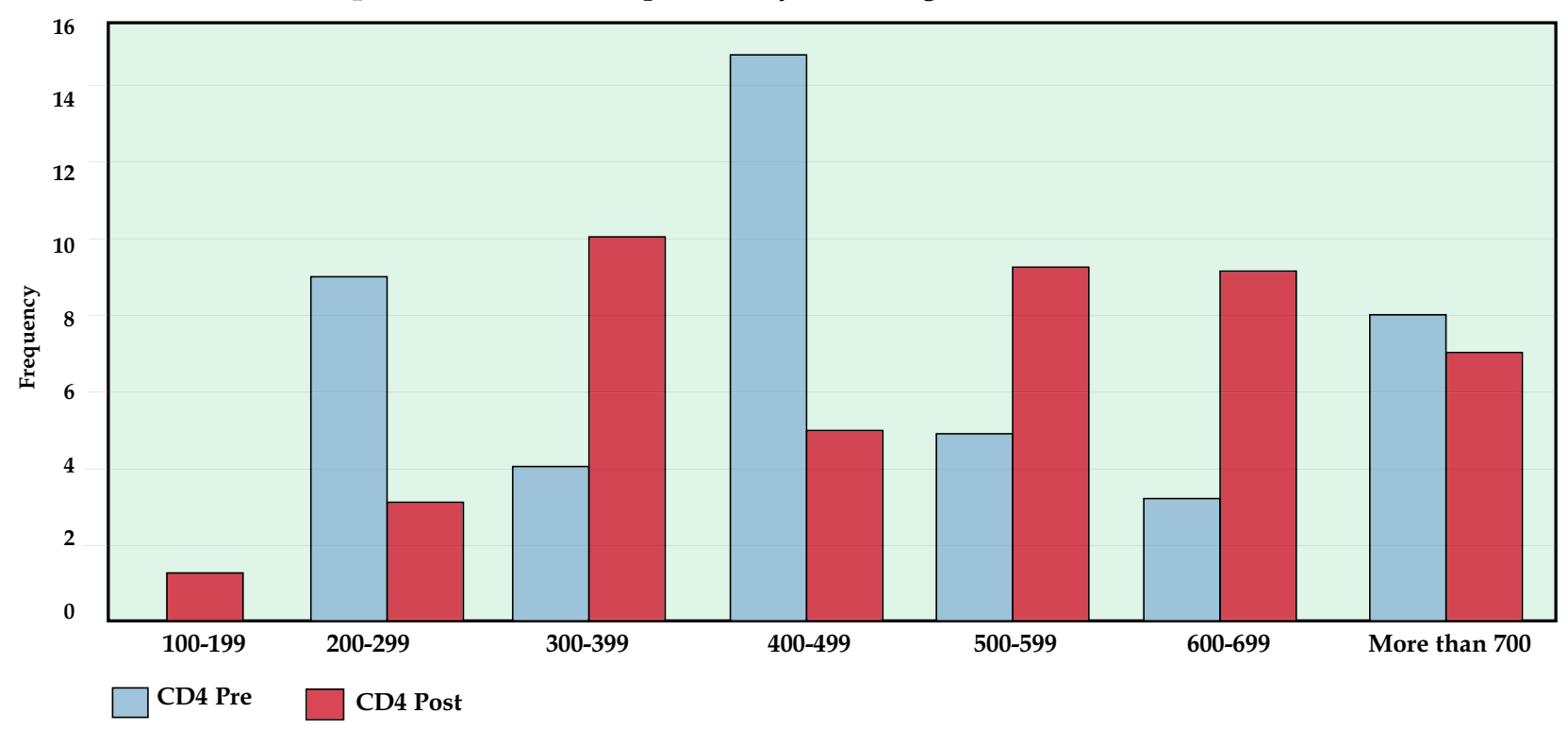




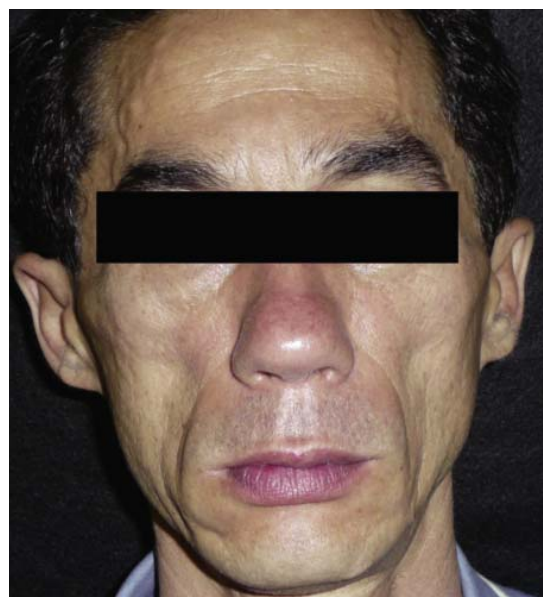

FIGURE 1: Patient before treatment of FL with PMMA implant. The patient had a CD4 count of 581 cells $/ \mathrm{mm}^{3}$

\section{DISCUSSION}

Patients in this study were evaluated in relation to HIV / AIDS by measurements of viral load and CD4 count 3 months before treatment and 6 months after treatment.

The markers used for assessment of disease progression were CD4 count and plasma viral load, which are the most accurate and widely used in HIV/AIDS infection. ${ }^{17}$

There is a well-established relationship between the number of circulating CD4+ lymphocytes and susceptibility to infection. Response to antiretroviral therapy, as measured by CD4 + count and HIV viral load, is associated with slower disease progression and reduced incidence of death. Studies have also shown that the greatest reductions in viral load are associated with greater improvements in clinical outcome. Even modest reductions of HIV RNA in the plasma are associated with reduced risk of subsequent opportunistic infections. ${ }^{18}$

Before treatment of $\mathrm{FL}$, the average CD4 + count of study patients was 493.97 and $82 \%$ of patients had undetectable viral load. Skeie et al. showed that patients in their study also had well-controlled HIV infection with an average CD4 of 520 cells/microliter, with a variation of more or less 320 cells, and $70 \%$ had a viral load of 50 viral copies $/ \mathrm{ml}^{15}$

This study showed an increase in the percentage of patients with undetectable viral load, that is, less than 50 viral copies per $\mathrm{ml}$ of blood, which increased from $82 \%$ before treatment to $88.6 \%$ after treatment. However, this increase was not significant.

The increase in CD4 count after treatment was statistically significant. This is something new in the

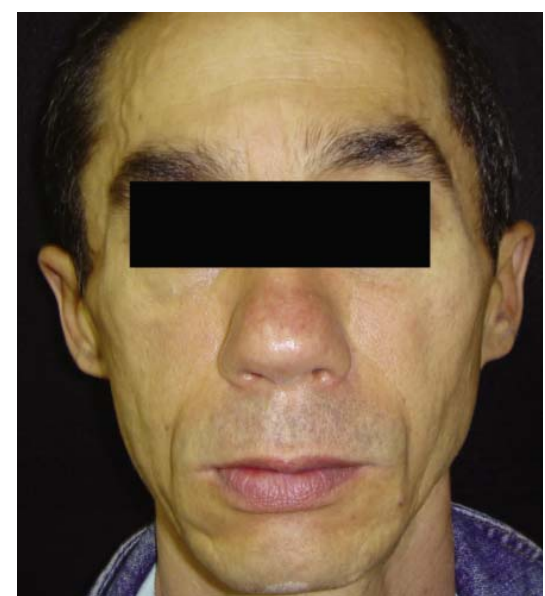

Figure 2: The same patient after PMMA implantation. Six months after the end of treatment, the patient presented a CD4 count of 1485 cells $/ \mathrm{mm}^{3}$, the highest increase observed in this study literature, as no study that was carried out in the last 20 years and that evaluated and proved the effect of FL treatment on CD4 count was found, at the time this study was conducted, in the MEDLINE and PubMed databases.

Considering that plasma levels of HIV -1 ribonucleic acid (RNA) and CD4 + lymphocyte count are the most important variables that determine the rate of progression of AIDS $^{19}$ and the well-established relationship between the number of circulating CD4 + lymphocytes and susceptibility to infection, the importance of this finding becomes evident, as it can reveal the influence of FL treatment on the progression of HIV/AIDS. ${ }^{18}$

This finding may reflect the influence of the psychological condition of patients as a determiner of their immune status. Improved self-esteem and better quality of life of patients treated with cutaneous implants have been reported..$^{15,16}$

Ironson et al. suggest that viral load is more sensitive to psychological influences than CD4 count. ${ }^{20}$ However, in the present study, the significant variation found, which is sometimes attributed to the psychological impact of the treatment, refers exclusively to CD4 count.

Several studies have demonstrated the influence of psychological factors on the immune system. Depression has been involved in a faster decline of CD4 cells as well as progression to AIDS and death. ${ }^{20}$ Similarly, stress has also been involved in the decline of CD4 cells and progression to AIDS. ${ }^{20}$

A historical breakthrough in the knowledge about the influence of the psychological state on 
immunity was a publication by Soloman in 1964 . Since then, studies about how behavior and emotions can modulate the immune system have become more frequent. Laboratory findings have shown transient immune changes in the conditions of acute stress. One possibility is the acute secretion of hormones responsive to stress, particularly catecholamines, which can change a number of aspects of the immune system, such as the distribution of some cell subpopulations in peripheral blood circulation. ${ }^{21}$

Stress factors resistant to changes in behavior, especially those considered unpredictable or uncontrollable, can be continuously associated with elevated stress-responsive hormones, even after repeated exposure. This condition leads to deregulation of the endocrine and immune systems, as well as changes in health status, in response to vaccines and wound healing. ${ }^{21}$ Some factors of chronic stress that have already been identified are isolation and exposure to harsh environments. These situations are sometimes present in the life of patients with HIV/ AIDS, especially when they are FL carriers. ${ }^{21}$

Mood swings are also related to changes in the immune system. A negative mood is associated with reduced natural killer cells (NK) in women. ${ }^{21}$ HIV patients with a positive attitude about their health showed a slower immune decline, later establishment of symptoms and longer survival. ${ }^{21}$

In HIV patients, a more rapid progression of the disease has been associated with stressful events and less cumulative social support. ${ }^{21}$ These patients may experience psychological responses to stressors that may contribute to immune deficiency. ${ }^{22}$

The association between immunological function and personal relationships is one of the most robust findings of neuropsychoimmunology. The activity of NK cells and proliferative response of peripheral blood leukocytes to mitogenic stimuli were associated with groups who had greater social support. ${ }^{21}$ Likewise, individuals with greater social support respond better to the vaccine against the hepatitis B virus. Individuals with fewer social ties are more susceptible to respiratory viruses. The presence of anxiety/anguish and poorer interpersonal relationships seemed to be related with a negative regulation of the immune system in a series of studies. ${ }^{21}$

One of the greatest impacts of FL is on the social relations of the patient. Rejection and isolation add to the stress of possible disease disclosure. The feeling of rejection has been associated with changes in peripheral leukocyte cell count and deregulation of the immune response. ${ }^{21}$

Improvement in the social relations of the patients may contribute to enhance the immune system.
Studies show that close relationships, such as marriage, which are chronically abrasive or stressful, may lead to persistent deregulation of the immune system. ${ }^{21}$

Neuropsychological interventions have also shown a positive impact on the immune system, such as stress management through cognitive behavioral therapy. ${ }^{21}$ Usually, mourning causes a reduction in CD4 cells and increased markers of lymphocyte activation. Cognitive therapy upon the death of a close friend or partner due to the disease may be associated with a slower decline of CD4 cells. ${ }^{21}$

In a study of HIV-positive patients who were subjected to 10 weeks of cognitive therapy for stress management, they showed signs of immune system reconstitution after 6 to 12 months of follow-up. ${ }^{22}$ Stress reduction seemed related to the ability of the immune system to reconstitute T cells, possibly affecting the cellular immune response to antigens and protecting against opportunistic diseases. ${ }^{22}$ The habit of writing about emotions led to an increase in CD4 cells, but without changes in viral load. ${ }^{23}$ This and other studies are in agreement with the results of the present study regarding the significant effect that psychological factors have on the course of HIV infection.

Stress changes the immune function and affects different populations of immune cells in different ways, improving the responses of monocytes or depressing that of lymphocytes. ${ }^{24}$ The most frequently reported consequence of stress and depression has been suppression of the immune response. ${ }^{24}$

Since the description of the "general adaptation syndrome", the fundamental concepts about stress began to be clarified. As the syndrome could be caused by physical or psychological stimuli, it was natural to assume that the endocrine and central nervous system interacted in response to stress. ${ }^{25}$

It is known today that stimuli from the central nervous system can modulate an immune response. The endocrine system is responsible for many of the associations between the two systems. ${ }^{25}$

The endocrine system acts as the access gate to the psychological influences on health. Stress and depression can cause the release of pituitary and adrenal hormones that have multiple actions on the immune system. Social stress can thus increase catecholamines and cortisol. ${ }^{21}$ Stress, via secretion of glucocorticoids, alters the TH1/TH2 balance, favoring the TH2 immune response. As a consequence, there is a decrease in the cellular immune response and an increase in the humoral response. ${ }^{25}$ In addition, distressed individuals often adopt multiple risky behaviors, such as poor nutrition and inadequate sleep, they are more likely to abuse alcohol and other drugs, and 
they practice less physical activities. All these behaviors also lead to endocrine and immunological consequences. $^{21}$

The sympathetic nervous system also associates emotions with the immune system. ${ }^{21}$ Sympathetic stimulation leads to the release of adrenaline in the sympathetic nerve terminals and adrenaline secretion by the adrenal glands. The sympathetic fibers are closely tied with lymphoid organs, such as the spleen. ${ }^{25}$ Adrenaline and noradrenaline decrease the cellular immune response; the former by increasing interleukin 6 and the latter via alpha and beta-adrenergic receptors. ${ }^{26}$

Experimental studies have shown that injury to the brainstem nuclei, rich in noradrenergic neurons, leads to a reduction in the number of circulating CD4 + cells. ${ }^{26}$

Specific areas of the brain that modulate feelings, such as the amygdala and hypothalamus, are rich in peptides which, when secreted, can affect the behavior, metabolism and migration of immune cells, as well as their cytotoxicity and ability to produce antibodies. ${ }^{26}$ Negative emotions like depression or anxiety can affect cells of the immune system and positively or negatively regulate the release of proinflammatory cytokines. ${ }^{21}$

Communication between the immune system and the central nervous system is bidirectional, that is, immune system mediators may act on the central nervous system, inducing activation of the hypothalamic-pituitary axis. ${ }^{25}$

Approaches that reduce depression symptoms, including behavioral or pharmacological therapies, provide an opportunity to positively impact the immune system. These interventions will possibly result in the improvement of the physical and mental health and quality of life of HIV/AIDS patients. ${ }^{27}$

Even though the effect that cortisol, other hormones and other conditions mediated by the psychological state of the patient have on immunology has been described in the literature, it is questionable whether in cases of HIV patients, in whom there is depletion of immune cells that are directly attacked by the virus itself, the emotional and psychological state of the patient could somehow influence their immune status. ${ }^{28}$ The findings of this study suggest that it could.

Still another possibility to explain these findings would be that FL patients treated would have greater adherence to ARV therapy. Even if all patients in the study reported regular use of the same ARV before and after treatment, strict monitoring of adherence to ARV therapy should be conducted to exclude or confirm this possibility. However, two studies did not show statistically significant differences with regard to treatment adherence before and after FL treatment. $^{15}$

The finding of an increase in CD4 cells after treatment of FL strengthens the recommendation that this treatment should be always accessible to patients, integrating the therapeutic options for HIV/AIDS patients.

\section{CONCLUSION}

Treatment of FL with PMMA implants, which is today the treatment available in the public healthcare system in Brazil, showed a positive impact on disease progression, with a statistically significant increase in CD4 count after treatment $(\mathrm{p}=0.02)$. This data is unprecedented in the literature. This increase was probably due to the positive impact of the treatment on the emotional and psychological state of the patients.

In addition to the known benefits of the treatment of FL for the patients' well being, this new finding corroborates the importance of providing FL treatment in assistance programs for HIV/ AIDS patients.

With respect to viral load, there was no statistically significant change before and after treatment of FL with PMMA implants ( $p=0.67)$. 


\section{REFERENCES}

1. Carr A, Samaras K, Burton S, Law M, Freund J, Chisholm DJ, et al. A syndrome of peripheral lipodystrophy, hyperlipidaemia and insulinresistance in patients receiving HIV protease inhibitors. AIDS. 1998;12:F51-8.

2. Collins $\mathrm{E}$, Wagner $\mathrm{C}$, Walmsley S. Psychosocial impact of the lipodystrophy syndrome in HIV infection. AIDS Read. 2000;10:546-50.

3. Brasil. Ministério da Saúde. Secretaria de Vigilância em Saúde. Departamento de DST, AIDS e Hepatites Virais. Manual de tratamento da lipoatrofia facial: recomendações para o preenchimento facial com polimetilmetacrilato em portadores de HIV/AIDS. Brasilia: Ministério da Saúde; 2009. 44 p. (Série A. Normas e Manuais Técnicos).

4. Behrens GMN, Stoll M, Schimidt RE. Lipodystrophy syndrome in HIV infection: what is it, what causes it and how can it be managed? Drug Saf. 2000;23:57-76.

5. Cabrero E, Griffa L, Burgos A; HIV Body Physical Changes Study Group. Prevalence and impact of body physical changes in HIV patients treated with highly active antiretroviral therapy: results from a study on patient and physician perceptions. AIDS Patient Care STDS. 2010;24:5-13.

6. Chen D, Misra A, Garg A. Clinical review 153: Lipodystrophy in human immunodeficiency virus-infected patients. J Clin Endocrinol Metab. 2002;87:4845-4856.

7. Baril JG, Junod P, Leblanc R, Dion H, Therrien R, Laplante F, et al. HIV-associated lipodystrophy syndrome: A review of clinical aspects. Can J Infect Dis Med Microbiol. 2005;16:233-43.

8. Li HY, Silva ACCM, Santos S. Síndrome Lipodistrófica e HIV/AIDS. J Bras Aids. 2002;3:23-35.

9. Kavouni A, Catalan J, Brown S, Mandalia S, Barton SE. The face of HIV and AIDS: can we erase the stigma? AIDS Care. 2008;20:485-7.

10. Milinkovic A, Martinez E. Current perspectives on HIV-associated lipodystrophy syndrome. J Antimicrob Chemother. 2005;56:6-9.

11. Pujol RM, Domingo P, Xavier-Matias-Guiu, Francia E, Sanbeat MA, Alomar A, et al. HIV-1 protease inhibitor-associated partial lipodystrophy: clinicopathologic review of 14 cases. J Am Acad Dermatol. 2000;42:193-8.

12. Baril JG, Junod P, Leblanc R, Dion H, Therrien R, Laplante F, et al. HIV-associated lipodystrophy syndrome: A review of clinical aspects. Infect Dis Med Microbiol. 2005;16:233-43

13. Narins RS. Minimizing Adverse Events Associated with Poly-L-latic Acid Injection. Dermatol Surg. 2008:34:S100-4.

14. Sturm LP, Cooter RD, Mutimer KL, Graham JC, Maddern GJ. A systematic review of permanent and semipermanent dermal fillers for HIV-associated facial lipoatrophy. AIDS Patient Care STDS. 2009;23:699-714.

15. Skeie L, Bugge H, Negaard A, Bergersen BM. Large particle hyaluronic acid for the treatment of facial lipoatrophy in HIV-positive patients: 3-year follow-up study. HIV Med. 2010;11:170-7.

16. Moyle GJ, Brown S, Lysakova L, Barton SE. Long-term safety and efficacy of poly-Llactic acid in the treatment of HIV-related facial lipoatrophy. HIV Med. 2006;7:181-5.

17. Chandra PS, Gandhi C, Satishchandra P, Kamat A, Desai A, Ravi V, et al. Quality of life in HIV subtype $C$ infection among asymptomatic subjects and its association with CD4 counts and viral loads--a study from South India. Qual Life Res. 2006;15:1597605.

18. Lomar AV, Diament D. Terapia Anti-retroviral. In: Veronesi R, Focaccia R, editores. Tratado de infectologia. São Paulo: Atheneu; 2005. p. 235-41.

19. Rizzo LV. Imunopatogênese. In: Veronesi R, Focaccia R, editores. Tratado de infectologia. São Paulo: Atheneu; 2005. p.138-42.

20. Ironson G, O Cleirigh C, Fletcher MA, Laurenceau JP, Balbin E, Klimas N, et al. Psychosocial factors predict CD4 and viral load change in men and women with human immunodeficiency virus in the era of highly active antiretroviral treatment. Psychosom Med. 2005;67:1013-21.

21. Kiecolt-Glaser J, McGuire L, Robies TF, Glaser R. Psychoneuroimmunology: psychological influences on immune function and health. J Consult Clin Psychol. 2002;70:537-47.
22. Antoni MH, Cruess DG, Klimas N, Maher K, Cruess S, Kumar M, et al. Stress Management andlmmune System Reconstitution in Symptomatic HIV-Infected Gay Men Over Time: EffectsonTransitionalNaiive T Cells (CD4+CD45RA+CD29+). Am J Psychiatry. 2002:159:143-4.

23. Petrie KJ, Fontanilla I, Thomas MG, Booth RJ, Pennebaker JW. Effect of written emotional expression on immune function in patients with human immunodeficiency virus infection: a randomized trial. Psychosom Med.2004:66:272-5.

24. Paik IH, Toh KY, Lee C, Kim JJ, Lee SJ. Psychological stress may induce increased humoral and decreased cellular immunity. Behav Med. 2000;26:139-40.

25. Alves GJ, Palermo-Neto J. Neuroimunomodulação: sobre o diálogo entre os sistemas nervoso e imune. Rev Bras Psquiatr. 2007:29:363-9.

26. Kooker M. Mind, immunity and health - the science and clinical application of psychoneuroimmunology. CME. 2008;26:18-20.

27. O Connell-Edwards C, Jones DJ. CD4 count and physical symptoms among urban African American mothers with HIV: an examination of the role of optimism and depressive symptoms. J Clin Psychol Med Settings. 2008:15:322-30.

28. Ulla S, Remor EA. Psiconeuroimunologia e infecção por HIV: realidade ou ficção? Psicol Reflex Crit. 2002;15:113-9.

\author{
MAILING ADDRESS: \\ Flávia Machado Gonçalves Soares \\ SHIS QI 27 conjunto 01 casa 07 - Lago Sul \\ 71675100 - Brasília - DF \\ Brazil \\ E-mail: flaviamachadosoares@gmail.com.br
}

How to cite this article: Soares FMG, Costa IMC. HIV-Associated facial lipoatrophy treatment: the impact on the infection progression assessed by viral loadand CD4 counting. An Bras Dermatol. 2013;88(4):570-7. 